\title{
Who Do Immigrants Marry? Partner Choice Among Single Immigrants in Germany
}

\author{
Amparo González-Ferrer
}

This article analyses the factors leading single immigrants in Germany to marry a native partner, a co-national immigrant residing in Germany, or a co-national residing in the country of origin. Assimilation hypothesis and the importance of numerical constraints within the marriage market are generally confirmed for the case of mixed marriages. In contrast, the practice of importing spouses and its relation with integration reveals more complex. Differences between men and women in their propensity to import partners from origin, and how these propensities relate to education are particularly puzzling. While the practice of importing a partner is related to low educational levels for men, this does not seem to be the case for women. The Lievens' hypothesis, which suggests that immigrant women may use traditional forms of marriage to achieve modern goals such as living independently from their own and their in-law relatives after getting married, is not able to account for this result.

\section{Introduction}

After the recruitment of foreign workers was stopped in the mid-seventies, European receiving states were compelled by international law to admit new foreign entries due to family reunification. This type of migration was expected to end quickly, when recruited workers who decided to stay at their destination brought the relatives they had left behind at the moment of migration. However, adult foreign inflows have not died out but, rather, continue. One of the main sources of this ongoing inflow of adult migration to Western Europe is the large number of immigrants' children who import their marriage partners from their countries of origin, instead of marrying other co-nationals already living in the country of immigration.
Despite its numerical importance, conventional portrayals of postwar migration lack a thorough analysis of family-linked forms of migration. Postwar migration within Europe is typically described as a two-stage process with a first wave of single workers (mainly males) followed by a second one made of (mainly) wives and children who joined their relatives after the halt on recruitment (Castles and Miller, 1993). Spouses and children are all grouped together as tied-movers and no distinction is made between genuine family reunification and family-forming migration (Coleman, 1994, 2004; Kofman, 1999, 2004). In this paper, I examine the process of family formation among immigrants in Germany and, more particularly, the factors underlying the marital choices of immigrants who marry during their stay in Germany. 


\section{Mixed Marriages and the Importation of Spouses: Assimilation and Marriage Market's Constraints}

In his review of the literature concerned with the factors underlying intermarriage and homogamy, Kalmijn mentions three types of factors that shape individuals' partner choices: (1) the preferences of the individuals for certain characteristics in a spouse, (2) the influence of the social group of which they are members and, (3) the potential constraints imposed by the structure of the marriage market where they are searching for a spouse (Kalmijn, 1998).

In the context of immigration, individual preferences (the first set of factors) have been the focus of the analyses inspired by the assimilationist approach, which predicts higher rates of intermarriage for the second and subsequent generations and for the more educated individuals within the immigrant group. When they reach marriageable age, second generation immigrants have spent their whole lives in the host country, are fluent in its language and have only attended its school system. Furthermore, some of them may have even acquired its nationality. All these circumstances, which imply partial or total socialization within the culture of the host country, increase their chances of establishing normalized contacts with members of the native population and will probably favor the development of personal values that soften prejudices and stereotypes about the "ideal" partner.

On the other hand, the acquisition of country-specific education by second generation immigrants, in particular of high level degrees, is also expected to increase their opportunities of meeting native potential partners. This is especially applicable in countries like Germany where the strong link between the vocational training system and the labour market produces strong job segmentation between Germans and minority ethnic groups (Blossfeld and Mayer, 1988; Müller et al., 1998; Granato and Kalter, 2000). In addition, higher education is also believed to weaken attachments with the group of origin and, consequently, to blur the cultural barriers against marriage out of the own group (Hwang et al., 1997, cited in Kalmiijn, 1998: 401).

Along with individual characteristics that indicate more or less assimilation into the host society, the structure of the marriage market has been also emphasized as a key factor for explaining the marital behaviour of minority groups like immigrants (the third set of variables in Kalmijn's scheme). The 'opportunity theory' formulated by Blau in the late seventies (Blau 1977, 1994) underlined, among others, the constraints for individuals' marital choices that derive from sex imbalances within the (partial) marriage market where individuals search for a partner, and from the size of the own group within the local marriage market. The larger the size of the own group, the more (statistical) chances of endogamous contacts, and increasing sources of social control as well. Accordingly, a negative relationship between the own group's size and propensity to mixmarry is expected. In contrast, sex imbalances within the own group are likely to increase intermarriage rates for the minority sex at least, since the fewer marriageable women (men) within the same group the more likely they will be to marry a woman (man) from outside.

The empirical evidence available so far has widely confirmed the predictions made by both the 'assimilationist' and the 'structuralist' approaches with respect to the propensity to mix-marry among immigrants, both in the US (Lieberson and Waters, 1985, 1988; Alba and Golden, 1986; Lee and Yamanaka, 1990; Pagnini and Morgan, 1990; Kalmijn, 1993; Kulczycki and Lobo, 2002; Rosenfeld, 2002) and in Europe (Kane and Stephen, 1988; Lievens, 1998; Klein, 2001; Botelho and Aagaard-Hansen, 2002).

Compared with mixed marriages, the practice of importing partners from the country of origin is generally seen as the type of marital choice that indicates the lowest level of assimilation among immigrants. Individuals who import their partner reveal an intense preference for marrying a particular type of partner within their own ethnic group: one who still lives in the origin country and, therefore, has no contact with the host country. Although sex imbalances within immigrant populations are, at least, partially responsible for male immigrants importing their partners, the few studies available to date on this issue have rather remarked the role of traditional values and the wish for 'unspoiled' wives in explaining the practice of importing brides, especially among Turks (Lievens, 1999; Celikaksoy et al., 2003). ${ }^{1}$

The preference for imported partners among immigrant women, though, cannot be interpreted as the logical response to the shortages of marriageable men within the own immigrant group since the numerical predominance of males remains in the middle generation and, sometimes, even in the second generation as well. The existing literature has typically referred to what Kalmijn calls 'the influence of the social group of reference' and, more precisely, to the pressures exerted by the woman's family as the most decisive factor in these cases. ${ }^{2}$ 
The survival of substantial migratory pressure and the practice of arranging marriages within the own kinship group in some sending countries have made migrant's single daughters a valuable asset for their parents. By arranging a marriage of this type, the bride's parents often obtain higher bride 'prices' from the groom's family in exchange for the possibility of legal admittance to Western Europe. In addition, the bride's parents may also express a sense of loyalty to their own origins, especially if the groom comes from the own family at origin. In fact, several authors have highlighted the numerical importance of consanguineous marriages within some immigrant groups in Western European countries (Reiners, 1998; Haug, 2002).

Apart from these potential benefits for the bride's family, by importing a partner the importer woman may secure a better position - in terms of bargaining power within the couple because she is the one who already knows the country where the couple will settle. In his analysis of the marital choices of Turk and Moroccan immigrants in Belgium, Lievens (1999) emphasized this aspect of marriage migration involving female importers and concluded that 'women may marry an imported partner in order to satisfy modern goals' (717). However, similar studies carried out for Turkish and other Muslim immigrant communities in the Netherlands and Denmark do not find support for such a hypothesis (Hooghiemstra, 2001; Celikaksoy et al., 2003).

\section{The German Immigration Experience}

The acute labour shortages after World War II led the German authorities to actively recruit foreign labour in Italy (1955), Greece (1960), Spain (1960), Turkey (1961) and Yugoslavia (1968). The presence of the foreign workers was intended to be temporary and a rotation system was established accordingly. However, the tendency to permanent settlement by a large fraction of the guestworkers became apparent quite soon (Herbert, 1990; Martin, 1998). In 1973, labour recruitment was put to an end in order to soften the social tensions and to protect native workers from the forthcoming recession. By then, one in eight workers in Germany was a foreigner, approximately 40 per cent of them had a permanent residence and work permit and many had already fetched their families to Germany (Herbert, 1990).

Although the ban on recruitment had an immediate effect on labour inflows, the immigrant population continued growing due to the increasing number of asylum seekers and, above all, to chain migration related to marriage of the guest-workers' offspring. The legal restrictions imposed in 1981 to limit the entry of spouses of aliens who entered Germany as children of guest workers, or who were born in Germany, were soon revealed to be insufficient and marriage migration remains one of the major channels of new immigration to Germany nowadays.

Some fragmentary pieces of information seem to suggest that intermarriage between Germans and foreigners has slightly increased during the last decades, and that couples involving an imported partner constitute a substantial fraction of the total number of marriages between foreigners in Germany. According to Strassburger (2001, 2004), the number of visas issued by the German Consulates in Turkey to Turkish citizens for joining their nonGerman spouse in Germany amounted to approximately 61 per cent of total weddings involving at least one Turkish citizen residing in Germany in 1996. However, official statistics do not yet allow an adequate analysis of these phenomena (Klein, 2001; Strassburger, 2001).

\section{Dataset and Sample Description}

The German Socio Economic Panel (GSOEP) is a longitudinal dataset that collects information on individuals and households living in Germany. ${ }^{3}$ Since its inception in 1984, GSOEP contains two different samples, one of which over-sampled households with a foreign head from Turkey, the former Yugoslavia, Italy, Spain and Greece (sample B in GSOEP terminology). Apart from the information obtained through face to face interviews held annually with each of the surveyed individuals, the GSOEP also includes a set of biographical files with retrospective information on family and work biographies since the age of 16. By combining all these files, I have reconstructed the partner choices of individuals of foreign origin who have married during their stay in Germany.

The final working sample is made up of 1097 individuals. ${ }^{4}$ It includes three immigrant generations: first (individuals who immigrated at 16 or older), middle (immigrated at age between 6 and 15, both included) and second generation (immigrated younger than 6 or were born in Germany to immigrant parents). ${ }^{5}$ The first generation represents half of the total sample, the middle generation a third, and the second generation the remaining 17 per cent (see Table 1). The small number of individuals of second generation in the sample 
Table 1 Sample descriptives

\begin{tabular}{lcccc} 
Variable & Mean & SD & Minimum & Maximum \\
\hline $\begin{array}{l}\text { First } \\
\text { generation }\end{array}$ & 0.50 & 0.50 & 0 & 1 \\
$\begin{array}{l}\text { Middle } \\
\text { generation }\end{array}$ & 0.33 & 0.47 & 0 & 1 \\
$\begin{array}{l}\text { Second } \\
\quad \text { generation }\end{array}$ & 0.17 & 0.38 & 0 & 1 \\
$\begin{array}{l}\text { Sex } \\
\quad(1=\text { female })\end{array}$ & 0.39 & 0.49 & 0 & 1 \\
$\begin{array}{l}\text { Years of } \\
\quad \text { education }\end{array}$ & 9.6 & 1.9 & 7 & 18 \\
$\begin{array}{l}\text { Sex ratio } \\
\text { Group size }\end{array}$ & 0.45 & 0.19 & 0 & 0.92 \\
$\begin{array}{l}\text { Date of } \\
\quad \text { marriage }\end{array}$ & 1982 & 440 & 3 & 1,484 \\
$\mathrm{~N}$ & 1097 & & 1960 & 2001 \\
\hline
\end{tabular}

Source: GSOEP 1984-2002. Unweighted data.

(189, of which only 89 were born in Germany) calls for caution when interpreting the results concerning this group. In fact, in GSOEP only 20 per cent of the immigrants' children born in Germany were already married as of 2002, indicating that our second-generation sub-sample might be over-representing individuals who marry at younger ages.

The average number of 'years of education prior to marriage' in the sample is rather low (9.6 over a minimum of 7), which reflects both the non-qualified profile of immigrant labour from the sixties and seventies, and the wide educational gap between native and immigrant youth in Germany (Granato and Kalter, 2002; Riphahn, 2002). ${ }^{6}$ Thirty-nine per cent of the sample are individuals of Turkish origin, 25 per cent are Italians, 12 per cent Spaniards, 12 per cent Greeks and another 12 per cent are from the former Yugoslavia.

'Group size' refers to the size of each individual's national group in Germany the year before his/her marriage, and 'sex ratio' measures the number of single men (women) older than 15 over the number of single women (men) older than 15 for each individual's nationality and year before her (his) marriage. ${ }^{7}$ The five immigrant groups under consideration suffered strong sex imbalances during the observation period (19602002) and, with the exception of the Greeks in the early nineties, males always out-numbered females.

The dependent variable 'type of partner' is coded 0 if the partner chosen is a native German, 1 if the partner is another co-national immigrant living in Germany at the time of marriage, and 2 if the partner is someone imported from the immigrant's country of origin. Native Germans have been identified by combining the information about place of birth and nationality prior to marriage; imported partners are defined as immigrants who do not live in Germany at the time of their marriage and marry someone who has lived in Germany at least two years prior to marriage.

Table 2 reveals that the dominant strategy in couple formation, especially for immigrant women, is marrying other co-national immigrant (71.19 per cent of women and 47.16 per cent of men choose this option). Immigrant women marry natives less than their male counterparts ( 9.6 versus 15.97 per cent). They also import fewer partners from their countries of origin than their male counterparts (19.2 versus 36.87 per cent). By origin, importing partners is typical of Turks but also important for male immigrants from the former Yugoslavia. Mixed marriages, on the other hand, are more common among immigrants from the former Yugoslavia than for any other group.

\section{Results and Discussion}

Table 3 reports the estimated coefficients of a logistic multinomial regression that examines the effects of the covariates previously described (both individuals' characteristics and structural constraints within the marriage market) on the probability of marrying a native partner versus marrying a co-national immigrant (upper part), and on the probability of importing a partner versus marrying a co-national immigrant in Germany (bottom part). Analytically, the multinomial logit model can be thought of as two simultaneously logit models in which two possible outcomes are compared against a third category of reference (Long, 1997: 151). Accordingly, I will comment on the obtained results separately for the outcome 'marrying a native' versus marrying a co-national, and for the outcome 'importing a partner' versus marrying a co-national. In addition, it is important to remember that in non-linear regression models such as multinomial logit, no single approach to interpretation can fully describe the relationship between a variable and the outcome probability, since such an effect always depends on the value of the remaining covariates (Long, 1997: 61). In order to ease the reading, I will plot the predicted probabilities of each outcome for specific values of the covariates included in the model (see below).

The results reported in the upper part of Table 3 widely support the predictions of both the assimilationist and the structuralist approaches concerning intermarriage 


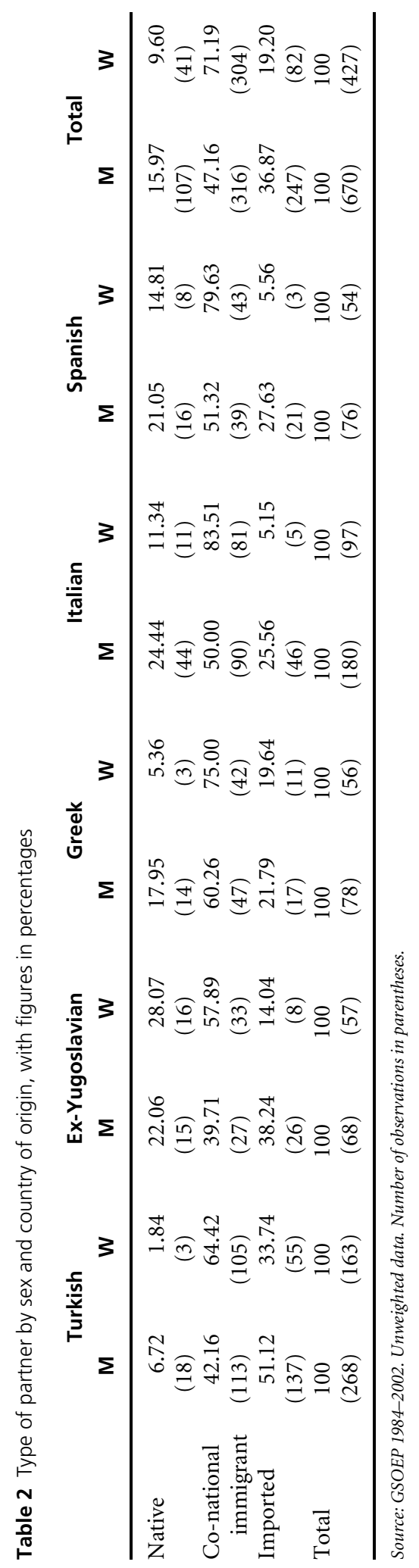


Table 3 Multinomial logit coefficients for type of partner (co-national immigrant = reference category)
(1)
(2)
(3)
(4)
(5)
$\begin{array}{cc}\text { Only } & \text { Only } \\ \text { men } & \text { women }\end{array}$

Native

$-0.74^{\star *}$

First generation (ref. middle) $-0.59^{* *}$

$(0.25)$

$-1.06^{\star *}$

$-0.34$

$(0.29)$

Second generation (ref. middle)

$0.82^{* *}$

$(0.27)$

$0.59^{*}$

$(0.27)$

$0.83^{\star *}$

$0.75^{\star *}$

$(0.31)$

Sex (ref. men)

$-1.16$

$(0.27)$

$(0.28)$

0.18

(0.22)

$(0.37)$

$-0.06$

(0.37)

Years in education

$0.23^{\star *}$

$0.24^{* *}$

(0.37)

$\begin{array}{ccc}(0.05) & (0.05) & (0.05) \\ 2.20^{* *} & 2.36^{* *} & 0.80\end{array}$

Ex-Yugoslavian (ref. Turk)

$(0.35)$

$(0.36)$

$0.89^{\star *}$

$0.88^{* *}$

$-0.91$

$(0.37)$

$(0.38)$

$1.53^{* *}$

$1.45^{\text {** }}$

$(0.30)$

$(0.30)$

Spanish

$1.50^{* *}$

$1.61^{\star *}$

Sex ratio

$-4.57^{\star *}$

(1.04)

$-0.33$

$(0.29)$

$0.59^{*}$

$(0.31)$

0.56

(1.15)

Sex $\times$ years in education

Constant

$$
\begin{array}{ccc}
-4.38^{* *} & -3.01^{* *} & -0.29 \\
(0.56) & (0.63) & (0.88)
\end{array}
$$

$-0.59^{*}$

$(0.35)$

0.61

0.53

(0.40)

(0.54)

$1.37^{\star *}$

$(0.57)$

Imported

First generation (ref. middle

0.09

$-0.04 \quad-0.15$

Greek

$(0.25)$
$-1.09^{* *}$

$(0.25)$

$-1.09^{* *}$

$(0.25)$
$-1.25^{\star *}$

$(0.26)$

$-1.41^{\star *}$

(0.20)

(0.22)

Spanish
$0.20^{* *}$

$(0.05)$

$(0.49)$

(0.54)

0.21

(0.52)

$-0.01$

(0.43)

$-1.97^{* *}$

$(0.61)$

$-0.78$

$(0.48)$

$-0.31$

$-1.09^{*}$

(0.62)

(0.55)

$-3.76^{\star *}$

$-4.95^{\star *}$

$(1.01)$

(1.08)

$(0.000)$

$-0.004^{* *}$

(0.0006)

$0.20^{* *}$

$(0.06)$

0.21

(0.52)

$-1.93^{* *}$

(0.61)

$-0.78$

(0.48)

$-1.09^{*}$

(0.62)

$-4.90^{* *}$

(1.07)

$-0.004^{* *}$

(0.00)

$1.13^{* *}$

$(0.42)$

$2.31^{* *}$

(0.43)

$1.82^{\star *}$

(0.42)

\subsection{7}

(0.88)

$1.14^{\star *}$

$(0.42)$

$2.33^{\star *}$

(0.43)

$1.85^{\star *}$

$(0.42)$

$-0.034$

(0.11)

0.005

(0.95)

$-0.42^{\star *}$

(0.21)

$-0.21$

(0.25)

0.33

(0.33)

$-0.05$

(0.04)

$-0.25$

(0.39)

$-1.02^{\star *}$
(0.21)

$-0.23$

(0.25)

$-2.31^{* *}$

(0.90)

$-0.14^{* *}$

(0.05)

$-0.22$

$(0.39)$

$-1.04^{* *}$

$(0.44)$

$-1.36^{* *}$

(0.36)

$-1.20^{* *}$

(0.44) $0.20^{\star *}$

$(0.06) \quad(0.10)$

$\begin{array}{ll}0.82 & 1.40\end{array}$

$(0.72)$

$-0.89$

$(0.74)$

$-0.43$

(0.56)

$-0.47$

(0.76)

$-8.48^{\star *}$

(1.83)

$0.00^{\star *}-0.004^{\star \star}$

$(0.00) \quad(0.001)$

$0.84^{\star} \quad 2.55^{\star *}$

$(0.49) \quad(0.97)$

$2.38^{\star *} \quad 3.73^{\star *}$

(0.55) (0.99)

$1.98^{* *} \quad 3.07^{* *}$

(0.57)

(0.92)

$0.64 \quad-5.66^{*}$

(1.06) (3.01)

$-0.22-0.97^{* *}$

(0.26) (0.38)

$-0.04 \quad-0.56$

(0.34) (0.39)

$-1.29^{* *}$

(0.36)

$\begin{array}{cc}-1.74^{\star \star} & -1.17^{\star \star} \\ (0.42) & (0.44)\end{array}$

$\begin{array}{cc}-1.74^{* *} & -1.17^{\star *} \\ (0.42) & (0.44)\end{array}$

$(0.42)$

(0.44)

$\begin{array}{cc}-0.13^{\star *} & 0.12 \\ (0.05) & (0.07) \\ 0.75 & -0.77 \\ (0.61) & (0.76) \\ -0.88 & -0.60 \\ (0.58) & (0.83) \\ -1.12^{\star *} & -1.66^{\star *} \\ (0.44) & (0.73) \\ -0.41 & -1.98^{\star *} \\ (0.62) & (0.93) \\ & \text { continued }\end{array}$

$-1.19^{\star *}-1.08^{\star *}$

(0.27)

$(0.27)$ 
Table 3 (continued)

\begin{tabular}{|c|c|c|c|c|c|c|c|}
\hline Sex ratio & & $\begin{array}{l}-4.62^{\star \star} \\
(0.83)\end{array}$ & $\begin{array}{c}-4.41^{* *} \\
(0.85)\end{array}$ & $\begin{array}{c}-4.35^{\star \star} \\
(0.89)\end{array}$ & $\begin{array}{c}-4.34^{\star \star} \\
(0.90)\end{array}$ & $\begin{array}{c}-6.59^{\star \star} \\
(1.74)\end{array}$ & $\begin{array}{c}-3.17^{\star} \\
(1.78)\end{array}$ \\
\hline Group size & & & $\begin{array}{c}-0.0008^{\star *} \\
(0.0004)\end{array}$ & $\begin{array}{c}0.0005 \\
(0.0005)\end{array}$ & $\begin{array}{c}0.0005 \\
(0.0005)\end{array}$ & $\begin{array}{c}0.0009 \\
(0.0006)\end{array}$ & $\begin{array}{c}0.001 \\
(0.001)\end{array}$ \\
\hline (Ref. cohort 1960-1974) & & & & & & & \\
\hline Marriage cohort 1974-1980 & & & & $\begin{array}{c}-1.24^{\star *} \\
(0.28)\end{array}$ & $\begin{array}{c}-1.27^{\star *} \\
(0.28)\end{array}$ & $\begin{array}{l}-1.20^{* *} \\
(0.33)\end{array}$ & $\begin{array}{c}-1.67^{\star \star} \\
(0.61)\end{array}$ \\
\hline Marriage cohort 1981-1990 & & & & $\begin{array}{c}-1.18^{\star *} \\
(0.31)\end{array}$ & $\begin{array}{c}-1.17^{\star *} \\
(0.32)\end{array}$ & $\begin{array}{l}-1.06^{\star *} \\
(0.40)\end{array}$ & $\begin{array}{c}-1.28^{\star *} \\
(0.64)\end{array}$ \\
\hline Marriage cohort 1991-2002 & & & & $\begin{array}{c}-1.28^{\star *} \\
(0.34)\end{array}$ & $\begin{array}{c}-1.24^{\star *} \\
(0.34)\end{array}$ & $\begin{array}{l}-1.40^{* *} \\
(0.45)\end{array}$ & $\begin{array}{c}-0.98 \\
(0.65)\end{array}$ \\
\hline Sex $\times$ years in education & & & & & $\begin{array}{l}0.28^{\star *} \\
(0.09)\end{array}$ & & \\
\hline Constant & $\begin{array}{l}0.91^{\star *} \\
(0.42)\end{array}$ & $\begin{array}{l}2.35^{\star *} \\
(0.51)\end{array}$ & $\begin{array}{l}3.31^{\star *} \\
(0.68)\end{array}$ & $\begin{array}{l}2.86^{* *} \\
(0.69)\end{array}$ & $\begin{array}{l}3.70^{* *} \\
(0.76)\end{array}$ & $\begin{array}{c}3.62^{\star *} \\
(0.84)\end{array}$ & $\begin{array}{c}1.12 \\
(1.88)\end{array}$ \\
\hline Log likelihood & -919 & -898 & -888 & -853 & -848 & -566 & -260 \\
\hline $\mathrm{N}$ & 1097 & 1097 & 1097 & 1097 & 1097 & 670 & 427 \\
\hline
\end{tabular}

Source: GSOEP 1984-2002. Unweighted data. ${ }^{*}$ Significant at 0.10; ${ }^{* *}$ significant at 0.05. Standard errors in parentheses.

behaviour among immigrant individuals in Germany. When only individual characteristics are considered (Model 1), the propensity to marry native partners appears to have increased over generations; first generation immigrants are less likely to marry a native partner than members of the middle generation, and secondgeneration individuals are more likely to mix-marry than their middle generation counterparts (the reference category). On the other hand, a positive effect of education on intermarriage behaviour is also detected $(\beta=0.23$, in Model 1). Results are not affected by the inclusion of a set of three dummy educational variables that indicate low (less than 9), medium (between 9 and 11) and high (11 and more), instead of the continuous variable 'years of education' reported in previous tables (results available upon request). However, given the difficulties of establishing skills and degrees equivalences across educational systems, and the small variation in this variable, I prefer to keep the continuous variable to control for the effects of education in further estimations.

The propensity to marry native partners versus conational immigrants varies greatly by country of origin. All ethnic groups in my sample are more likely to marry a German partner than Turks (the reference category). People from the former Yugoslavia appear to be the most prone to engage in mixed couples and Greeks the least so, only slightly more than Turks. Differences in propensities to mix-marry are also found between men and women. In line with some previous evidence, immigrant women are substantially less likely to marry German partners than men ( $\beta=-1.17$, see Model 1$)$.

However, some of these differences across origin and gender disappear after controlling for structural constraints in the respective marriage market. The effect of the variables 'sex ratio' and 'group size' also confirm the predictions of the structural opportunity theory (Blau, 1994). The more marriageable people of the opposite sex within the own community are in the host country, the more likely they are to marry another co-national immigrant instead of a German partner. In fact, the effect of the sex ratio indicator is particularly large and significant at 95 per cent $(\beta=-4.57$, see Model 2$)$. This effect holds even after controlling for the size of the group which is also inversely related to the propensity to mix-marry ( $\beta=-0.003$, see Model 3$)$. The most remarkable finding of Models 2 and 3 is the modification of the previously found differences between sexes and ethnic groups in their propensity to marry a native versus a co-national immigrant. First of all, controlling for sex imbalances eliminates the women's smaller propensity to mixmarry (see the coefficient for 'sex' in Model 2, which is not significant). Secondly, when the group's size control is also added in Model 3, differences between ethnic groups change substantially. Now, it is the Greeks who appear to be the least likely to marry a German partner (significant at 90 per cent level), while the former Yugoslavs, Italians and Spaniards become undistinguishable from Turks (the reference category) in their propensity to 
engage in mixed marriages (i.e. the coefficients become much smaller in size and not significant at all in Model 3). However, the positive effect of education and the growing tendency to engage in mixed couples over generations remain.

Finally, Model 4 adds a set of dummy variables distinguishing among four marriage cohorts: 1960-1974 (the reference category), 1974-1980, 1981-1990 and 1991-2002. This is clearly a rough way of measuring potential changes in the patterns of partner's choices over time. However, taking into consideration the long period of time under analysis (40 years), I considered it necessary to include a control for changes across time. The results show an increasing tendency to mix-marry comparing to the marriage cohort '1960-1974' (omitted category). In order to find out whether the differences between the three other categories aside from the omitted one were significant or not, I refitted the model changing the reference category and confirmed that the increasing trend to mix-marry among immigrants seems to have stopped and almost reversed in the nineties (the sign for the marriage cohort '1990-2002' is negative and almost significant when compared against '1981-1990').

The effects of the individual and structural covariates on the choice of an imported partner versus a conational immigrant are reported in the bottom part of Table 3. Results in Model 1 suggest that the practice of importing partners from the country of origin among people of foreign origin in Germany does not match the predictions of the assimilationist approach. First of all, no significant differences emerge between the first and second generation compared to the middle one (the reference category), although the sign of the coefficients points in the right direction if the importation of spouses is basically conceived as an expression of traditional behaviour. The sign of 'years of education' is negative in line with the assimilationist expectation, but it does not reach statistical significance.

The coefficients in Model 1 also suggest that the practice of importing spouses is more common among men and particularly prevalent in some ethnic groups, especially Turks. Women are much less likely to import than their male counterparts $(\beta=-1.11$, see Model 1$)$ and Turks (the omitted category) are considerably more likely to import than immigrants from Italy, Greece and Spain. Individuals from the former Yugoslavia, though, are not significantly different from Turks in their propensity to import (coefficient $\beta=-0.4$ is not significant). The absence of significant differences between Turks and ex-Yugoslavians in their propensity to import their spouses from origin may be due to two different factors.
On the one hand, a considerable number of immigrants from the former Yugoslavia are Muslims for whom the practice of arranged marriages is relatively common. On the other, Turks and Yugoslavs were the groups that suffered more severely the consequences of the increasingly stringent controls on immigration imposed since the mid-seventies because substantial emigration pressures persisted in these countries during the eighties and nineties, due to several causes. Accordingly, marriage migration among people from these countries has been often argued to be a strategy developed by individuals to circumvent immigration restrictions.

When the statistical chances of finding a partner within the own ethnic group in Germany is controlled for (by inclusion of sex ratio in Model 2), women's lower propensity to import vanishes, which confirms that sex imbalances are partially responsible for the practice of importing partners among men. The propensity to import also drops as the size of the respective immigrant community in Germany increases.

Results in Model 4 show that marriages involving an imported partner were much more likely for the '1960-1974 cohort' (the reference category) than for the more recent ones, which would reject the idea that marriage migration developed mainly after the halt on labour recruitment in 1973 as a means to circumvent the increasing controls on further immigration from nonEC countries to Germany. Moreover, no significant differences in the propensity to import (versus marrying a co-national) emerge between the '1974-80', '1981-1990' and '1991-2002' marriage cohorts (I checked this by changing successively the reference category and refitting the model). These results are not in contradiction with the statement previously made about marriage migration being one of the most important sources of adult migration to Germany today, though. New entries of foreigners due to the importation of spouses by residents of immigrant origin have effectively intensified over time but only in relative terms, that is, in comparison to other forms of migration such as single adult migration and reunification of wives left behind at the time of the husband's migration. ${ }^{8}$ In the same line of reasoning, it is not surprising that the coefficient for the first generation becomes negative and significant at the 95 per cent level once that the aforementioned differences between the successive marriage cohorts are controlled for $(\beta=-0.42$, see Model 4$)$.

Finally, Model 5 adds the interaction term 'sex $\times$ years of education', in order to analyse whether the practice of importing spouses may entail different meanings for men and women. Effectively, the results reported for 
Model 5 show that the interaction term is positive, which suggests that the impact of education on women's and men's propensity to import differs significantly (see 'sex $\times$ eduyrs' $\beta=0.28$ in Model 5 , bottom part of Table 3 ). Furthermore, after introducing the interaction term, the negative effect of being a woman (compared to being a man) becomes larger and strongly significant (see 'sex' coefficient $\beta=-2.31$, Model 5). The same occurs with the main effect of 'years of education', which now captures the effect of 'years of education' for men; it also becomes larger, negative and significant (see 'eduyrs' coefficient $\beta=-0.14$, Model 5).

In Figures 1 and 2 I have plotted the cumulated predicted probabilities of marrying a native, a co-national immigrant and an imported partner for different values of the 'years of education' variable for Turkish middle generation immigrants who married in the nineties, in order to illustrate more clearly how marital choices vary depending on the years of education prior to marriage. These probabilities were computed considering all the controls included in Model 5. ${ }^{9}$

Figure 1 shows that for middle generation Turkish men with less than 11 years of education, marrying a conational immigrant is the most likely choice (around 50 per cent) and marrying a German woman the least likely one (between 10 and 15 per cent). For those with 11 years of education, marrying a co-national continues being the most common choice versus importing and mix-marrying, which are approximately equally likely. But when years of education is above 11, the chances of importing a woman from Turkey reduces substantially (less than 15 per cent), while marrying a German woman becomes the most preferred choice, especially for the most educated ones (almost 60 per cent).

Partner choices made by middle generation Turkish women are very similar to those of men's at the lowest level of education (seven years): marrying a co-national immigrant is the most likely choice (about 50 per cent), importing a man from Turkey is the second preferred choice (less than 40 per cent) and marrying a German man the least likely option (around 10 per cent). However, for highly educated women, the most likely choice is not a German partner, as it is for men, but to import a Turkish man from the country of origin (between 42 and 51 per cent). It seems that women face much stronger barriers to marrying outside the own group than men. If German partners are hardly considered for middle generation Turkish women, their decision reduces to a choice between a co-national immigrant and an imported partner. The reasons why they mostly

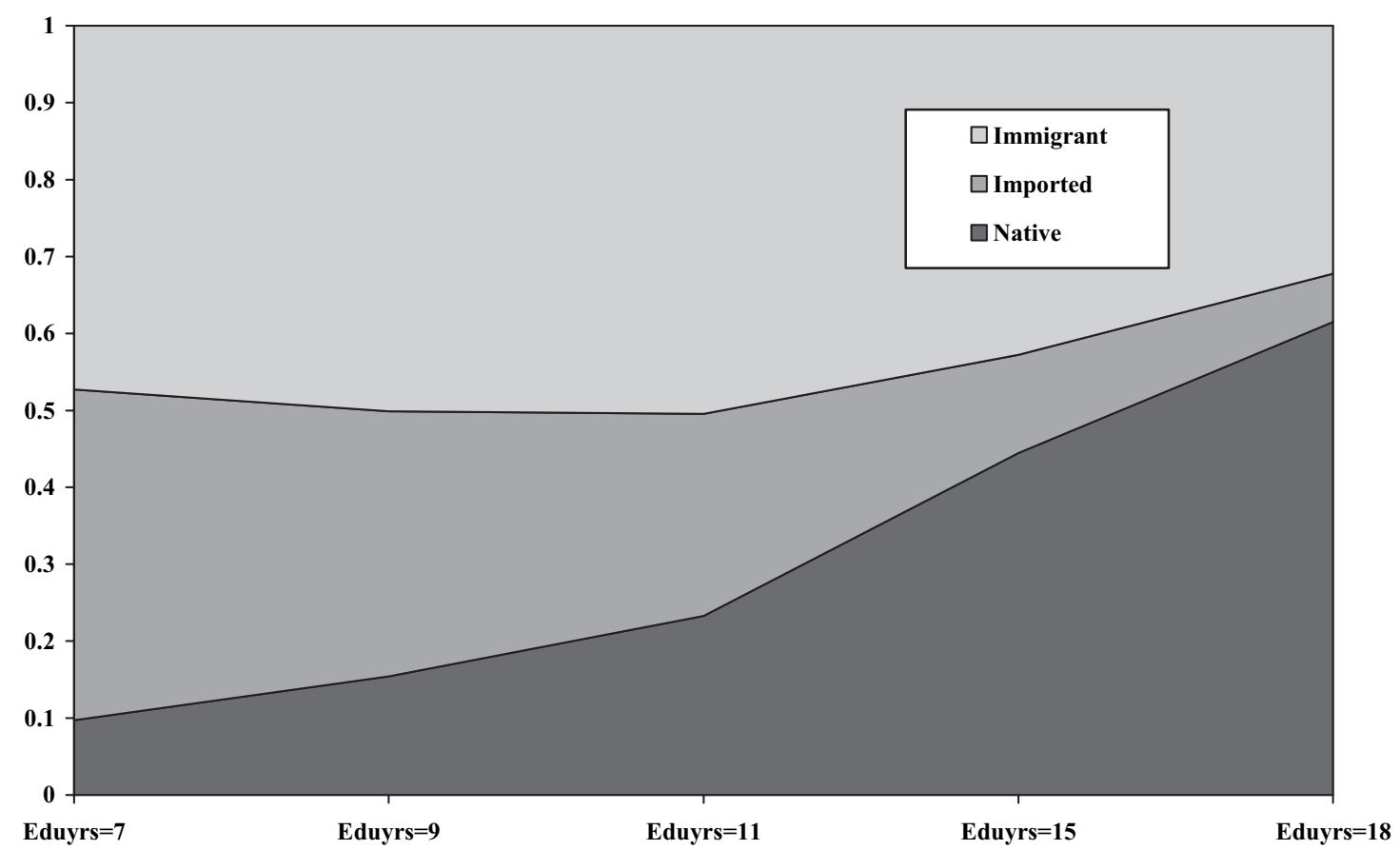

Figure 1 Effect of years of education on partner type for middle generation Turkish males who married in the 90s 


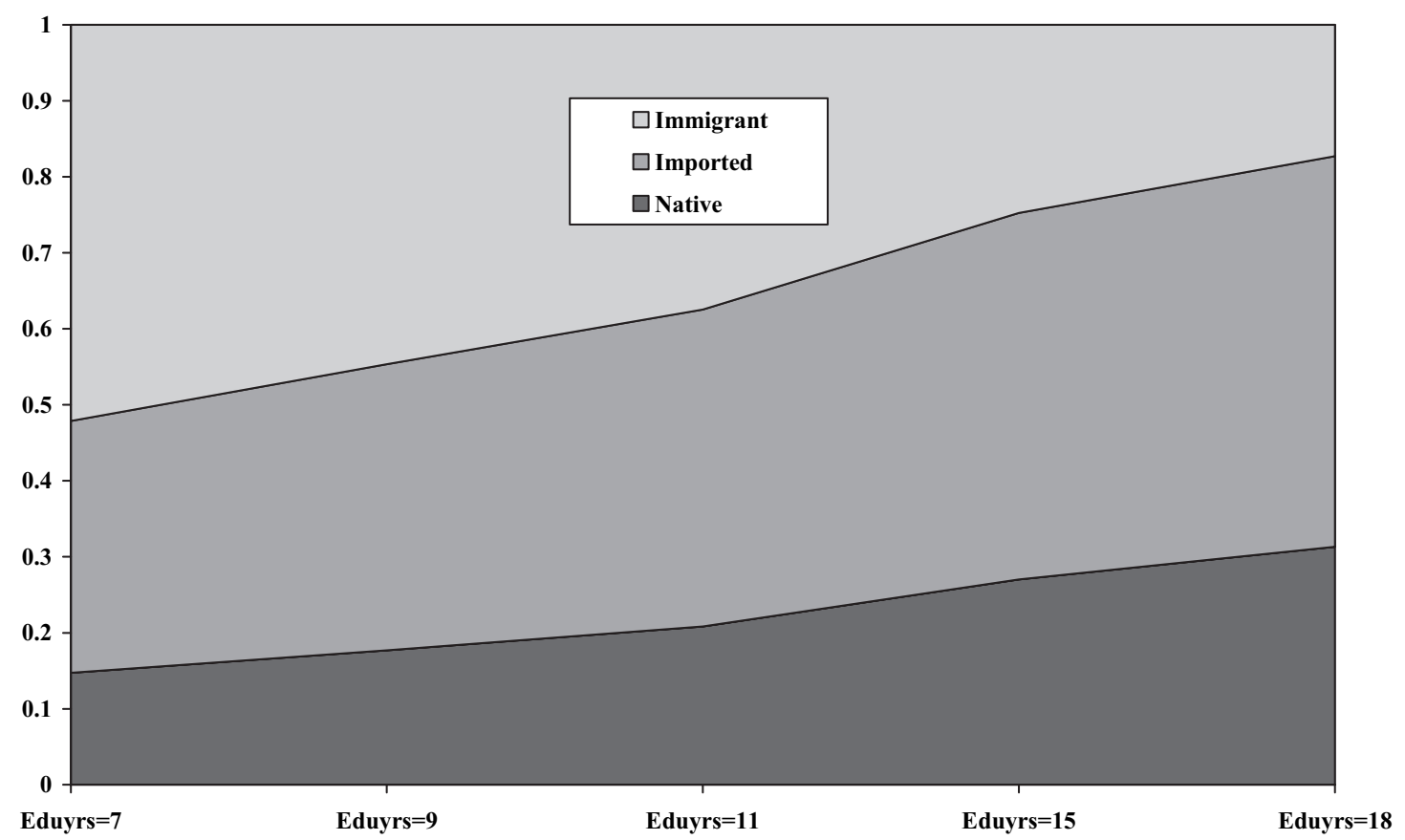

Figure 2 Effect of years of education on partner type for middle generation Turkish females who married in the 90s

prefer an imported partner is something that remains unexplained.

The patterns shown in Figure 1 and Figure 2 clearly illustrate that the effect of education differs significantly between sexes. In fact, this is precisely what the interaction term in Model 5 implies: that the difference between the effect of 'years of education' when sex is 0 (man) and when sex is 1 (woman) is positive and significant at 95 per cent $(-0.14+0.28=0.14)$. In other words, that the effect of years of education on the propensity to import a partner is more positive for women than for men, which does not imply necessarily that the effect of years of education is positive for women themselves.

For estimating the effect of the years of education on partner choices of men and women the best strategy would be to run two separate models for each sex. This is what I have done in the last columns in Table $3 .{ }^{10}$ For men, the positive effect of education on marrying a German woman and the negative one on importing a partner are both confirmed (note, for instance, that the coefficient of 'years of education' in Model 5 and in the model fitted only for men is practically the same: $\beta=-0.14$ in Model 5 and $\beta=-0.13$ in the new model). For women, the positive effect of the years of education on mix-marrying remains stable. The effect of education on the women's propensity to import keeps the expected sign although it does not reach the significance level.

These results imply we cannot affirm that education increases the probability of an immigrant woman to import her partner from the country of origin but only that, while the practice of importing spouses among men is clearly related to low educational levels, this is not necessarily the case for women. Although apparently surprising, this result can be understood in the light of the different incentives that immigrant parents face when intervening in the marital choices of their daughters and sons. I have already mentioned that most single people willing to migrate in sending countries like Turkey are men. For many of them, marrying a single Turkish woman who already resides in Germany nowadays constitutes the best way to get legal admittance to the German labour market. As a result, immigrant parents with single daughters in Germany often receive high bride-price offers from more than one male next of kin at origin (Böcker, 1994). Single sons, on the contrary, are not so sought after by female prospective immigrants at origin. Bearing in mind the different set of incentives faced by immigrant parents depending on the sex of their children, it is not a surprise that education has a stronger freeing effect on the marital decisions of men than on those of women. 
On the other hand, years of education prior to marriage are directly related to the age of entering into first marriage. A single daughter may be allowed by her parents to stay in school until his 'arranged' partner is ready for marriage and migration, or until she fulfils the requirements established in German law for permitting her future husband to join her in Germany. These requirements consist basically of having resided in Germany for an uninterrupted period of eight years, which is the period of residency established for issuing a residence permit. Such legal conditions may delay marriage for couples involving an imported partner compared to couples made up of two middle generation immigrants who already reside in Germany at the time of their marriage. If this is the case, the woman's decision to import a partner might have been made prior to the decision to stay longer in school and, therefore, the association between the two variables would not imply a causal relationship of education on imported partners but rather the other way around. ${ }^{11}$

There are other possible explanations for the differential effect of education on the propensity to import for men and women. In his interpretation of the positive association between educational level and propensity to import for Turkish women in Belgium, Lievens suggested that by importing their husbands immigrant women may assure extra-power within the couple and increase their chances of living independently of their in-laws - who stayed at origin - and of their own relatives living in the immigration country, because it is not commonly accepted for a man to live with his in-laws. However, Lievens never tested whether his explanation was empirically grounded or not.

To do so, I have identified in GSOEP which of the immigrant couples in my sample lived with other relatives besides their spouse immediately after marriage, and which did not. Then I investigate, first, whether those who import their partner are more likely to live in extended households than others, which would confirm the view that the practice of importing spouses is linked to more traditional forms of living. Second, I will focus on a more specific group on which the Lievens' argument should apply, and analyse whether highly educated Turkish women are effectively more likely to live without other relatives at home than women with nonimported partners, as Lievens hypothesized.

The information for the dependent variable was missing for 64 couples, so the sample size is now reduced to 1033 individuals. In addition, the information about the kinship relation to the head of the household was collected only since GSOEP's inception in 1984, which implies some measurement error for couples that married prior to this date. ${ }^{12}$ This is the reason why I estimated the model separately for the whole sample (column 1 of Table 4), the sub-sample of immigrants who married after 1982 (column 2), non-Turks (column 3), Turks (column 4), Turkish men (column 5), Turkish women (column 6) and more educated Turkish women (column 7).

The results reported in Table 4 strongly support the idea that the practice of importing spouses is related to a more traditional understanding of 'family life'. After controlling for country of origin, age at migration, age at marriage, years of education, having worked before marriage and gender, the effect of having an imported spouse substantially increases the probability that the couple lives with other relatives - aside from the two partners and their children - after marriage (see columns 1 to 6). In addition, this is the case not only for Turks, who are the group most prone to import, but also for the other national groups (see column 3). Therefore, it seems that the proposition that the practice of importing spouses and living in extended households are related is empirically borne out by the data regardless of ethnic particularities.

The expected lower propensity of the second generation immigrants to live in extended households - from an assimilation stand point - only arises when the sample is restricted to people who married after 1982, which eliminates most first generation immigrants from the sample and turns the middle generation into the reference category. Moreover, it seems that the change in post-marriage living arrangements between the middle (immigrated at age between 6 and 16) and the second generation (immigrated younger than 6 or were born in Germany) has occurred for Turkish women but not for men. Gender differences within the Turkish group are not limited to the intensity of the intergenerational change in living arrangements after marriage, though. Comparing results in column 5 (Turkish men) and column 6 (Turkish women), it can be noted that education has no significant effect on the males' probability of living with other adult relatives besides their wife, whereas it significantly reduces the women's probability of sharing their household with someone else as well as their husband. In addition, having worked prior to marriage increases the probability of living in an extended household for Turkish men but not for women.

Finally, among Turkish women with more than nine years of education (column 7), being a second generation immigrant and having worked before marriage strongly reduces the probability of living in an extended 
Table 4 Coefficients estimates of logistic regression of living in extended household after marriage

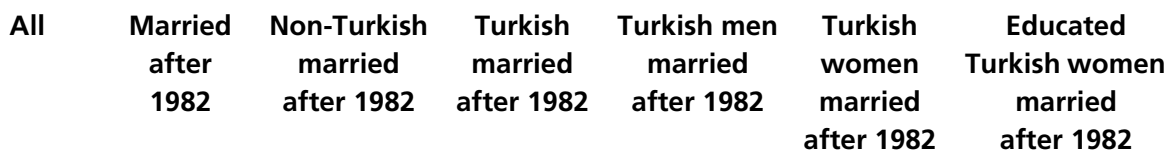

\begin{tabular}{|c|c|c|c|c|c|c|c|}
\hline Turkish & $\begin{array}{l}2.03^{* *} \\
(0.33)\end{array}$ & $\begin{array}{l}1.73^{* *} \\
(0.42)\end{array}$ & - & $\overline{-}$ & 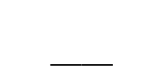 & 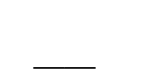 & 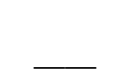 \\
\hline Ex-Yugoslavian & $\begin{array}{l}0.80^{*} \\
(0.43)\end{array}$ & $\begin{array}{l}1.25^{\star *} \\
(0.54)\end{array}$ & $\begin{array}{l}1.11^{\star *} \\
(0.53)\end{array}$ & 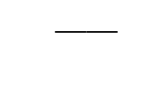 & 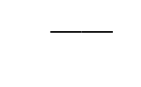 & - & 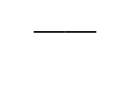 \\
\hline Greek & $\begin{array}{l}1.25^{\star *} \\
(0.42)\end{array}$ & $\begin{array}{l}1.47^{\star *} \\
(0.55)\end{array}$ & $\begin{array}{l}1.28^{* *} \\
(0.52)\end{array}$ & - & - & - & - \\
\hline $\begin{array}{l}\text { (Ref. first + middle } \\
\text { generation) }\end{array}$ & & & & & & & \\
\hline Second generation & $\begin{array}{c}0.24 \\
(0.22)\end{array}$ & $\begin{array}{l}-0.47^{\star *} \\
(0.23)\end{array}$ & $\begin{array}{c}-0.28 \\
(0.45)\end{array}$ & $\begin{array}{c}-0.56^{*} \\
(0.29)\end{array}$ & $\begin{array}{c}-0.001 \\
(0.41)\end{array}$ & $\begin{array}{l}-1.08^{\star *} \\
(0.45)\end{array}$ & $\begin{array}{l}-2.28^{\star \star} \\
(1.10)\end{array}$ \\
\hline Age at marriage & $\begin{array}{c}-0.24^{* *} \\
(0.03)\end{array}$ & $\begin{array}{l}-0.25^{\star *} \\
(0.05)\end{array}$ & $\begin{array}{c}-0.31^{\star *} \\
(0.08)\end{array}$ & $\begin{array}{l}-0.21^{\star *} \\
(0.06)\end{array}$ & $\begin{array}{c}-0.30^{* *} \\
(0.08)\end{array}$ & $\begin{array}{c}-0.14 \\
(0.08)\end{array}$ & $\begin{array}{c}-0.03 \\
(0.14)\end{array}$ \\
\hline Years of education & $\begin{array}{l}-0.03 \\
(0.05)\end{array}$ & $\begin{array}{l}-0.04 \\
(0.06)\end{array}$ & $\begin{array}{l}-0.18 \\
(0.11)\end{array}$ & $\begin{array}{c}-0.16^{*} \\
(0.09)\end{array}$ & $\begin{array}{l}-0.12 \\
(0.12)\end{array}$ & $\begin{array}{c}-0.31^{* *} \\
(0.15)\end{array}$ & - \\
\hline $\begin{array}{l}\text { Work before } \\
\text { marriage } \\
\text { (Ref. men) }\end{array}$ & $\begin{array}{c}0.24 \\
(0.21)\end{array}$ & $\begin{array}{c}0.51^{\star} \\
(0.27)\end{array}$ & $\begin{array}{l}-0.04 \\
(0.50)\end{array}$ & $\begin{array}{l}0.63^{\star *} \\
(0.51)\end{array}$ & $\begin{array}{l}0.92^{\star *} \\
(0.44)\end{array}$ & $\begin{array}{c}0.50 \\
(0.46)\end{array}$ & $\begin{array}{c}-1.90^{\star \star} \\
(0.97)\end{array}$ \\
\hline Sex & $\begin{array}{r}-0.38^{\star} \\
(0.17)\end{array}$ & $\begin{array}{l}-0.42^{\star *} \\
(0.21)\end{array}$ & $\begin{array}{c}-0.74 \\
(0.48)\end{array}$ & $\begin{array}{c}-0.41 \\
(0.25)\end{array}$ & - & - & - \\
\hline $\begin{array}{l}\text { (Ref. non- } \\
\text { imported partner) }\end{array}$ & & & & & & & \\
\hline Imported partner & $\begin{array}{l}1.03^{\star \star} \\
(0.22)\end{array}$ & $\begin{array}{l}1.86^{\star *} \\
(0.27)\end{array}$ & $\begin{array}{l}2.53^{\star \star} \\
(0.51)\end{array}$ & $\begin{array}{l}1.68^{\star *} \\
(0.32)\end{array}$ & $\begin{array}{l}1.80^{* *} \\
(0.38)\end{array}$ & $\begin{array}{l}1.54^{\star *} \\
(0.50)\end{array}$ & $\begin{array}{c}1.05 \\
(0.83)\end{array}$ \\
\hline Constant & $\begin{array}{l}2.04^{* *} \\
(0.85)\end{array}$ & $\begin{array}{l}3.53^{* *} \\
(1.10)\end{array}$ & $\begin{array}{l}2.93 \\
(1.84)\end{array}$ & $\begin{array}{l}5.62^{\star *} \\
(1.32)\end{array}$ & $\begin{array}{l}5.80^{* *} \\
(1.65)\end{array}$ & $\begin{array}{l}5.32^{\star *} \\
(1.86)\end{array}$ & $\begin{array}{c}1.49 \\
(3.24)\end{array}$ \\
\hline Log likelihood & -396 & -244 & -77 & -162 & -91 & -68 & -19 \\
\hline $\begin{array}{l}\text { Pseudo R2 } \\
\mathrm{N}\end{array}$ & $\begin{array}{c}0.2607 \\
1033\end{array}$ & $\begin{array}{l}0.3074 \\
549\end{array}$ & $\begin{array}{l}0.2856 \\
263\end{array}$ & $\begin{array}{l}0.1760 \\
286\end{array}$ & $\begin{array}{l}0.2146 \\
169\end{array}$ & $\begin{array}{l}0.1555 \\
117\end{array}$ & $\begin{array}{l}0.2627 \\
40\end{array}$ \\
\hline
\end{tabular}

Source: GSOEP 1984-2002. Unweighted data. ${ }^{*}$ Significant at $0.10 ;{ }^{*}$ significant at 0.05 . Standard errors in parentheses.

household after getting married. Although the effect of having an imported partner for this select group of women remains positive, the coefficient is not statistically significant. Therefore, and notwithstanding the data limitation problems, the Lievens' hypothesis that the more educated Turkish women may import their husbands as a means to free themselves from living with other relatives besides their husbands does not seem to be supported by our data.

\section{Conclusions}

The empirical analysis carried out in this article confirms the importance of both individual characteristics and structural factors on immigrants' decisions over their type of partner. Marrying a native and importing a partner from the country of origin emerge as alternatives clearly differentiated from one other, on the one hand, and from the most common choice of marrying another immigrant, on the other.

The results obtained generally confirm previous findings in the literature on intermarriage behaviour: second generation immigrants and the more educated ones are more likely to marry a native both for men and women. However, the analysis does not support the widespread idea that women are less prone to inter-marrying than men. In fact, the differential propensity to mix-marry between men and women disappears when sex imbalances within the marriageable population of the own 
ethnic group are controlled for. Moreover, accounting for the structure of the respective ethnic marriage market drastically modifies the differences between national groups. After controlling for sex ratio imbalances, group size differences and marriage cohort, the initially predisposition of Italians, Greeks and Spaniards to marry Germans is completely reversed, and the differences between Turks and immigrants from the former Yugoslavs vanish.

The choice between importing a partner from origin and marrying a co-national immigrant already in Germany is a little more complex. The main tenets from the assimilationist approach are not so clearly confirmed in this case. Middle generation and second generation are more likely to import their partners than their parents' generation. However, differences between the middle and second generation are not significant. The more balanced is the sex composition of the own ethnic group in Germany, the less likely are single immigrants to import their partners from origin. However, the propensity to import instead of marrying other co-national immigrants increases with the size of the own community in Germany. Over time, the tendency to import spouses seems to have declined for marriage cohorts compared to those immigrants who married prior to 1974 , which implies that the idea that marriage migration intensified after the halt on recruitment as a means to circumvent restrictive measures at the border must be rejected.

Finally, the differential impact of education on the propensity to import partners depending on whether the immigrant is a man or a woman is one of the most puzzling findings of the article. While male importers seem to be the least educated within their own group, women who import are not necessarily the least educated ones. The explanation for this result is far from clear. I explored the hypothesis suggested by Lievens that immigrant women, especially the most assimilated ones, may use a traditional form of marriage such as importation of spouses as a strategy for achieving modern goals like living independently from other relatives after marriage. Yet, the obtained results do not confirm this hypothesis. On the contrary, importing partners and living in extended households after marriage appear to be two facts strongly related to each other, also for women.

\section{Notes}

1. For a complete review of the issue of bi-national marriages and marriage migration among immigrants in Germany see Nauck (2001).
2. Note that while among men the choice of an imported bride is seen as a voluntary decision motivated by traditionalist considerations, women's decisions to import are often considered as decisions imposed by others. In the assimilationist rationale, the logical preference for middle and second generation immigrant women would be co-national immigrants or native partners, rather than imported ones.

3. For more on GSOEP structure and content see Hasiken-DeNew and Frick (2003).

4. Ninety-one per cent of them belong to sample B. The remaining 9 per cent of individuals are Turkish, Yugoslavian, Italian, Greek and Spanish surveyed in the other five samples (samples A, C, D, E and F) launched since 1984. By including foreign individuals in newer GSOEP samples, however, I only achieved a very limited update of the original 'foreigners' sample', which has narrowed over time due to general panel attrition and considerable return migration.

5. Individuals born in Germany to immigrant parents were assigned their mother's country of origin, since GSOEP provides no information on ethnic origin for individuals born in Germany.

6. This variable measures, respectively, the number of years of education completed the year before marriage for those who married after entering GSOEP (46 per cent), and the number of years in education reported in the first interview by those who had married prior toGSOEP's inception.

7. These two variables, sex ratio and group size, had to be constructed from GSOEP information due to the absence of complete official register figures for the whole period under study here.

8. I thank one anonymous reviewer for suggesting this clarification.

9. For computing the predicted probabilities, the coefficients estimated in Model 5 were applied to the following covariates' values: 'first generation', 'second generation', 'ex-Yugoslavian', 'Greek', 'Italian' and 'Spanish' were all set to 0; the dummy variables that indicate the marriage cohort of individuals were all set to 0, except the one indicating '1991-2002'. Finally, 'sex' was set to 0 for computing probabilities in Figure 1 (men), and to 1 in Figure 2 (women). The value of 'years of education' varies from 7 to $9,11,15$ and 18 (see the horizontal axis) and, consequently, the value of the interaction term is always 0 in Figure 1 (because sex $=0$ and, thus, 'sex $\times$ eduyrs' is necessarily 0 ), and it varies from 7 to $9,11,15$ and 18 in Figure 2 that draws the predicted probabilities for women (i.e. 'sex $\times$ eduyrs' $=(1 \times$ eduyrs $)=$ eduyrs $)$. 
10. I thank an anonymous reviewer for suggesting this second double check consisting of running separated regression for men and women.

11. In fact, in my sample, Turkish women from the middle generation who have imported their partners marry, on average, three years older than those who marry co-national immigrants.

12. It is difficult to anticipate the direction of such error, though. Newly married couples might be more likely to live with some other relatives at the beginning of their joint lives if they cannot afford their own housing, but couples who live on their own may incorporate new members like grandparents as they get older and more vulnerable.

\section{Acknowledgements}

I have received useful comments and suggestions from José Fernández-Albertos, Bernhard Nauck, Emilio Parrado, Yasemin Soysal, Filiz Garip and three anonymous referees. I am also very grateful for comments on a previous draft from participants to the Seminar 'Who do immigrants marry?' organized by the Sociology Department of the UNED (Madrid) in December 2004.

\section{References}

Alba, R. D. and Golden, R. M. (1986). Patterns of Ethnic Marriage in the United States. Social Forces, 65, 202-223.

Blau, P. M. (1977). Inequality and Heterogeneity. New York: The Free Press.

Blau, P. M. (1994). Structural Context of Opportunities. Chicago: University of Chicago Press.

Blossfeld, H.-P. and Meyer, U. (1988). Labor Market Segmentation in the Federal Republic of Germany: An Empirical Study of Segmentation Theories from a Life Course Perspective. European Sociological Review, 4, 123-140.

Böcker, A. (1994). Chain Migration over Legally Closed Borders: Settled Immigrants as Bridgeheads and Gatekeepers. The Netherland's Journal of Social Science, 30, 87-106.

Botelho, V. and Aagaard-Hansen, H. (2002). Mixed Marriages and Immigration in Denmark. Paper to be presented at the 2003 Annual Meeting of the Population Association of America, May 1-3, Minneapolis, USA.

Castles, S. and Miller, M. J. (1993). The Age of Migration. International Population Movements in the Modern World. Basingstoke, Hampshire: Macmillan.

Celikaksoy, A. et al. (2003). Marriage Migration: Just Another Case of Positive Assortative Matching? Aarhus School of Business Working Papers Series, 03-27.
Coleman, D. A. (1994). Trends in Fertility and Intermarriage among Immigrant Populations in Western Europe as Measures of Integration. Journal of Biosocial Science, 26, 107-136.

Coleman, D. A. (2004). Partner Choice and the Growth of Ethnic Minority Populations. Bevolking en Gezin, $33,7-34$.

Granato, N. and Kalter, F. (2002). Demographic Change, Educational Expansion and Structural Assimilation of Immigrants: The Case of Germany. European Sociological Review, 18, 199-216.

Hasiken-DeNew, J. P. and Frick, J. R. (2003). Desktop Companion to the German Socio-Economic Panel Study. Berlin: DIW (available at http://www.diw.de/ english/sop/service/dtc/dtc.pdf).

Haug, S. (2002). Familie, soziales Kapital und soziale Integration. Zur Erklärung ethnischer Unterschiede in Partnerwahl und generativem Verhalten bei jungen Erwachsenen deutscher, italienischer und türkischer Abstammung. Zeitschrift für Bevölkerungswissenschaft, 27, 393-425.

Hwang, S.-S. et al. (1997). Structural and Assimilationist Explanations of Asian American Intermarriage. Journal of Marriage and the Family, 59, 758-772.

Herbert, U. (1990). A History of Foreign Labor in Germany, 1880-1980. Ann Arbor: University of Michigan Press.

Hooghiemstra, E. (2001). Migrants, Partner Selection and Integration: Crossing Borders? Journal of Comparative Family Studies, 32, 609-626.

Kalmijn, M. (1993). Spouse Selection among the Children of European Immigrants: A Comparison of Marriage Cohorts in the 1960 Census. International Migration Review, 27, 51-78.

Kalmijn, M. (1998). Intermarriage and Homogamy: Causes, Patterns and Trends. Annual Review of Sociology, 24, 395-421.

Kane, T. and Stephen, E. H. (1988). Patterns of Intermarriage of Guestworker Populations in the Federal Republic of Germany: 1960-1985. Zeitschrift fur Bevölveskerungwissensschaft, 14, 187-204.

Klein, T. (2001). Intermarriages between Germans and Foreigners in Germany. Journal of Comparative Family Studies, 32, 325-346.

Kofman, E. (1999). Female 'Birds of Passage' a Decade Later: Gender and Immigration in the European Union. International Migration Review, 33, 269-99.

Kofman, E. (2004). Family-related Migration: A Critical Review of European Studies. Journal of Ethnic and Migration Studies, 30, 243-262.

Kulczycki, A. and Lobo, A. P. (2002). Patterns, Determinants and Implications of Intermarriage among Arab Americans. Journal of Marriage and Family, 64, 202-210.

Lee, S. M. and Yamanaka, K. (1990). Patterns of Asian American intermarriage and marital assimilation. Journal of Comparative Family Studies, 21, 287-305. 
Lieberson, S. M. and Waters, C. M. (1985). Ethnic Mixtures in the United States. Sociology and Social Research, 70, 43-52.

Lieberson, S. M. and Waters, C. M. (1988). From Many Strands: Ethnic and Racial Groups in Contemporary America. New York: Russell Sage Foundation.

Lievens, J. (1998). Interethnic Marriage: Bringing in the Context through Multilevel Modelling. European Journal of Population, 14, 117-155.

Lievens, J. (1999). Family-formation Migration from Turkey and Morocco to Belgium: The Demand for Marriage Partners from the Countries of Origin. International Migration Review, 33, 717-744.

Long, S. (1997). Regression Models for Categorical and Limited Dependent Variables. Thousand Oaks, California: Sage.

Martin, P. L. (1998). Germany: Reluctant Land of Immigration. German Issues, 21. Washington: The American Institute for Contemporary German Studies.

Müller, W. et al. (1998). Education and Labor Market Entry in Germany. In Müller, W. and Shavit, Y. (Eds) From School to Work. Oxford: Clarendon Press, pp. 143-188.

Nauck, B. (2001). Solidarpotenziale von Migrantenfamilien. Friedrich-Ebert-Stiftung, Gesprächskreis Migration und Integration.

Pagnini, D. L. and Morgan, P. (1990). Intermarriage and Social Distance among US Immigrants at the Turn of the Century. American Journal of Sociology, 96, 405-432.
Reniers, G. (1998). Post-migration Survival of Traditional Marriage Patterns: Consanguineous Marriage among Turkish and Moroccan Immigrants in Belgium. IPD Working Paper, Universiteit Gent, Brussels, Belgium.

Riphahn, R. (2002). Cohort Effects in the Educational Attainment of Second Generation Immigrants in Germany: An Analysis of Census Data. IZA Discussion Papers, no. 291.

Rosenfeld, M. (2002). Measures of Assimilation in the Marriage Market: Mexican Americans 1970-1990. Journal of Marriage and the Family, 64, 152-162.

Strassburger, G. (2001). Transstate Ties of the Second Generation. Marriages of Turks in Germany, German-Turkish Summer Institute Working Paper Series, No. 7/2001.

Strassburger, G. (2004). Transnational Ties of the Second Generation: Marriages of Turks in Germany. In Faist, T. and Ozveren, E. (Eds) Transnational Social Spaces. Agents, Networks and Institutions. Ashagate: pp. 211-223.

\section{Author's Address}

CEACS, Juan March Institute, C/Castelló 77, 28006 Madrid, Spain. Tel.: +34-91-431-03-54, Ext. 293; Fax: +34-91-431-51-35. E-mail: agonzalez@ceacs.march.es

Manuscript received: May 2005 